\title{
Global assays of hemostasis in the diagnostics of hypercoagulation and evaluation of thrombosis risk
}

\author{
Elena N Lipets ${ }^{1}$ and Fazoil I Ataullakhanov ${ }^{1,2,3,4,5,6^{*}}$
}

\begin{abstract}
Thrombosis is a deadly malfunctioning of the hemostatic system occurring in numerous conditions and states, from surgery and pregnancy to cancer, sepsis and infarction. Despite availability of antithrombotic agents and vast clinical experience justifying their use, thrombosis is still responsible for a lion's share of mortality and morbidity in the modern world. One of the key reasons behind this is notorious insensitivity of traditional coagulation assays to hypercoagulation and their inability to evaluate thrombotic risks; specific molecular markers are more successful but suffer from numerous disadvantages. A possible solution is proposed by use of global, or integral, assays that aim to mimic and reflect the major physiological aspects of hemostasis process in vitro. Here we review the existing evidence regarding the ability of both established and novel global assays (thrombin generation, thrombelastography, thrombodynamics, flow perfusion chambers) to evaluate thrombotic risk in specific disorders. The biochemical nature of this risk and its detectability by analysis of blood state in principle are also discussed. We conclude that existing global assays have a potential to be an important tool of hypercoagulation diagnostics. However, their lack of standardization currently impedes their application: different assays and different modifications of each assay vary in their sensitivity and specificity for each specific pathology. In addition, it remains to be seen how their sensitivity to hypercoagulation (even when they can reliably detect groups with different risk of thrombosis) can be used for clinical decisions: the risk difference between such groups is statistically significant, but not large.
\end{abstract}

Keywords: Global assays of hemostasis, Hypercoagulation, Thrombosis

\section{Introduction}

Thrombotic complications occur in many cases: they accompany or even induce innumerable disorders and states: atherosclerosis, infarction, stroke, pregnancy, trauma, surgery, sepsis, etc. Their danger is presently well recognized, and there are regulations on the use of antithrombotic agents for all patients with thrombotic risks. Such agents are presently available in a huge variety [1] and include direct and indirect coagulation factors inhibitors, antagonists of platelet activation and adhesion receptors, and also of platelet signaling.

However, there are unmet needs with regard to identification the patients at risk of thrombosis, individual

\footnotetext{
* Correspondence: ataullakhanov.fazly@gmail.com

${ }^{1}$ Center for Theoretical Problems of Physicochemical Pharmacology, Russian Academy of Sciences, Moscow, Russia

${ }^{2}$ National Research Center for Hematology, Moscow, Russia

Full list of author information is available at the end of the article
}

selection and correct dosing of these drugs, in particular for individual patients. There is always risk of bleeding (1-3\% for all antithrombotics at their recommended doses), and brain hemorrhage can be no less fatal than thrombosis. Traditional coagulation assays are insensitive to hypercoagulation and unable to evaluate thrombotic risks.

A possible solution is proposed by use of global, or integral, assays [2-4] that aim to mimic and reflect the major physiological aspects of hemostasis process in vitro. Here we review the existing evidence regarding the ability of both established and novel global assays (thrombin generation, thrombelastography, thrombodynamics, flow perfusion chambers) to evaluate thrombotic risk in specific disorders. The biochemical nature of this risk and its detectability by analysis of blood state in principle are also discussed.

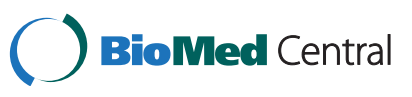


Pathophysiology of hypercoagulation and thrombosis

Before speaking about thrombosis risk evaluation and prediction of thrombosis using in vitro diagnostics, it is essential to discuss the biochemical nature of thrombus formation.

\section{Venous thrombosis}

Recent reviews on the venous thrombosis pathogenesis can be found in $[5,6]$. The basic principles of it were formulated by Virchov in 1859, who defined origin of thrombosis in his famous triad of disorders in blood composition, flow velocity or vascular wall. It is well established that venous thrombi are formed mostly as a result of fibrin formation (so-called 'red' thrombi rich in fibrin and entrapped red blood cells) with little if any contribution from platelet adhesion. It is not completely clear, however, how this process is triggered. Venous thrombi are attached to the vessel wall by fibrin [7], and in most cases the wall remains undamaged [8]. The most likely mechanism of triggering thrombosis involves endothelial activation. Upon blood flow stagnation, inflammation and/or hypoxia endothelial cells release the Weibel-Palade bodies containing von Willebrand factor (vWF) of increased length and P-selectin. The release enable attachment of platelets, monocytes, neutrophils [9] and their microparticles. Activated by hypoxia, cytokines, and lipopolysaccharides monocytes express Tissue factor (TF) [10], which stimulates clotting activation. Additional tissue factor is provided by microparticles derived from monocytes, cancer cells [11] and probable neutrophiles [9] depending on the primary disorder. Essential role can be played by contact activation from neutrophil extracellular traps (NET), extracellular chromatin fibers with a backbone of histones [9]; contribution of platelet- and endothelium-derived microparticles is possible [12]. Depending on the balance between procoagulant factors, their inhibitors and fibrinolysis, this endothelium activation might develop into full-scale thrombosis.

\section{Arterial thrombosis}

Arterial thrombosis is usually triggered by rupture of an atherosclerotic plaque. This leads to externalization of collagen, TF and vWF. As a result of rapid flow velocity in arteries, the primary driving mechanism of arterial thrombosis is platelet deposition with fibrin formation playing a secondary, thrombus-stabilizing role $[13,14]$. This is confirmed by predominance of platelets in such thrombin (so-called 'white' thrombi) and by efficiency of antiplatelet agents [15]. Altered platelet adhesion and aggregation due to increased vWF concentration, decreased ADAMTS13 (a metalloproteinase, that cleaves vWF to smaller, less procoagulant forms), increased in vitro platelet aggregation after low concentrations of adenosine diphosphate and/or epinephrine (sticky platelet syndrome) are associated with arterial thrombosis $[16,17]$.

However, there are indications of hypercoagulation state in the plasma of patients suffering from arterial thrombosis: circulating factors XIa and TF were detected in patients following ischemic cerebrovascular events [18], in stable angina patients [19], in patients with systolic heart failure due to ischemic cardiomyopathy [20]. In some of the intravital arterial thrombosis animal models monocyte- and endothelium-derived microparticles were deposited in thrombi [11]. Even double-drug antiplatelet therapy in acute coronary syndrome does not prevent a $\sim 10 \%$ yearly risk of a recurrence, while addition of rivaroxaban significantly decreases the risk [21]. These data indicate that blood coagulation contribution in arterial thrombosis should not be neglected.

\section{Microvascular thrombosis}

Originally, pathogenesis of thrombosis was primarily studied in large blood vessels. However, there has been a recent shift in the attention to the microvasculature and to the microcirculatory occlusion [22]. Probably, an important factor in this shift is that the most informative experimental models of thrombosis are microvascular ones [23]. Development of microthrombosis is usually related to TF expression by various cells, degradation of TFPI by neutrophil elastase, fXII activation by NETs released by neutrophils and enhanced by their interaction with platelets [24]. It is observed in multiple diseases (sepsis [25], cancer [26], infarction [27], thrombotic thrombocytopenic purpura [28]) and is a critical factor in the development of disseminated intravascular coagulation and organ dysfunction [29]. Among all types of thrombosis, microvascular thrombosis is most of all associated with plasma ability to coagulate overall increase, hypercoagulability [30].

\section{Specific causes of hypercoagulation}

Hypercoagulation state, usually meaning increased tendency of blood to clot, can be induced by numerous molecular mechanisms enumerated below.

Hypercoagulation in cancer is usually associated with expression of TF, cancer procoagulant (CP) and adhesion molecules. TF expression is induced by activation of oncogenes or inactivation of tumor suppressor genes [31]. Some of the circulating TF is associated with microparticles $[32,33]$ that also accelerate clotting by providing additional phosphatidylserine. $\mathrm{CP}$ is a cysteine protease with factor $\mathrm{X}$ activating properties [34]. Its role as a factor predictive of clinical thrombosis has not been successfully demonstrated. Mice models demonstrated that NETs also contribute significantly to hypercoagulation in cancer [35]. Adhesion molecules allow direct interaction 
of tumor cells with endothelium, platelets, and leukocytes, can induce formation of platelet microthrombi [36].

Normal pregnancy is associated with increase in fibrinogen (Fg), Factors VII, VIII, X, and VWF. Free protein $S$ is decreased secondary to increased levels of its binding protein, the complement component C4b. Plasminogen activator inhibitor type 1 (PAI-1) levels increase 5-fold [37]. Levels of PAI-2, produced by the placenta, increase dramatically during the third trimester [38]. For some complication of pregnancy, increased concentration of endothelial-derived and TF-positive microparticles was reported $[39,40]$.

Hormonal contraceptives increases concentrations of Fg, prothrombin (factor II) and factors VII, VIII and X, and reduction in coagulation inhibitors, such as antithrombin (AT) and protein S and tissue factor pathway inhibitor (TFPI). On the other hand, fibrinolysis is also stimulated: tissue plasminogen activator (tPA) activity is increased, while that of PAI-1 is decreased [41].

Diabetes leads to increase in adhesion and aggregation of platelets, as well as platelet-dependent thrombin formation. Changes in the platelet reactivity occur at the stage of megakariopoiesis. Leukocytes are also activated and expose aminophospholipids and TF, express adhesive molecules that promote interaction of leukocytes with endothelium and formation of leukocyte-platelet aggregates. Dysfunction of endothelium is observed. Concentrations of VWF, factor VII, and Fg are increased, those of AT, PC, endothelial thrombomodulin (TM) are decreased. Platelets, monocytes, endothelium demonstrate increased microparticle production. Levels of PAI-1 and tPA are decreased [42].

To summarize, there are several immediate reasons of high risk systemic thrombosis. First, there are materials that directly activate coagulation: circulating contact pathway-activating microparticles [43], circulating TF on cells or microparticles (in cancer or diabetes), factor XIa (ischemic cerebrovascular events, stable angina), cancer procoagulant, bacteria. The second category includes mechanisms that do not initiate clotting by themselves but may promote clotting propagation by shifting coagulation balance: increased level, activity or longevity of pro-coagulant factors (congenital, pregnancy, oral contraceptives, mutations like prothrombin G20210A [44] or factor V Leiden $[45,46])$, decreased concentration or function of the anti-coagulant molecules (congenital or consumptive deficiency of AT, PS, PC [47,48]), decreased fibrinolysis, ADAMTS13, increased vWF [16]. The data for several protrombotic states discussed in this article are summarized in Table 1, which attempts to relate mechanism of pro-coagulant changes, disorders that cause them, and the types of thrombosis supported by them.

\section{Detection of hypercoagulability: possible strategies}

Nature of pre-disposition of an individual to thrombosis may be either local or global. Local factors such as vessel wall damage, atherosclerotic plaque formation or blood flow stagnation remain naturally beyond functional laboratory assays of coagulation (although possibility to detect some markers of inflammation and damage in blood indirectly cannot be excluded). Other thrombotic events can be directly associated with global changes in blood composition. These systemic pro-thrombotic changes are called hypercoagulation. When thrombosis can be directly linked to hypercoagulability, several ways to determine it exist.

One way is to detect the specific cause: change in the coagulation factor or coagulation inhibitor concentration, presence of a circulating active factor, microparticles, change in fibrinolysis factor, vWF concentrations. While such research is important, these parameters appear to be innumerable and some of them (e.g. picomolar concentrations of factors) are extremely hard to measure. In addition, isolated information about specific

Table 1 The reasons of hypercoagulation in different states associated with risk of thrombosis discussed in the article

\begin{tabular}{|c|c|c|c|c|c|c|}
\hline $\begin{array}{l}\text { Background } \\
\text { state }\end{array}$ & Activating material & $\begin{array}{l}\text { Increased level of } \\
\text { procoagulant } \\
\text { zymogens }\end{array}$ & $\begin{array}{l}\text { Decreased level } \\
\text { of coagulation } \\
\text { inhibitors }\end{array}$ & $\begin{array}{l}\text { Fibrinolysis } \\
\text { abnormalities }\end{array}$ & $\begin{array}{l}\text { Other hemostasis } \\
\text { abnormalities }\end{array}$ & $\begin{array}{l}\text { Type of } \\
\text { thrombosis }\end{array}$ \\
\hline Cancer & TF, NET, MP & & & & $\begin{array}{l}\text { Cancer procoagulant, } \\
\text { adhesive molecules }\end{array}$ & $\begin{array}{l}\text { Venous } \\
\text { thrombosis }\end{array}$ \\
\hline Pregnancy & $\mathrm{TF}, \mathrm{MP}$ & $\mathrm{Fg}, \mathrm{VII}, \mathrm{VIII}, \mathrm{X}$ & Free protein $\mathrm{S}$ & PAI- $1 \uparrow, \mathrm{PAI}-2 \uparrow$ & $\begin{array}{l}\text { Thrombocytopenia, } \\
\text { platelets activation, WWF }\end{array}$ & $\begin{array}{l}\text { Venous } \\
\text { thrombosis, } \\
\text { Arterial } \\
\text { thrombosis }\end{array}$ \\
\hline $\begin{array}{l}\text { Oral } \\
\text { contraceptives }\end{array}$ & & $\mathrm{Fg}, \mathrm{II}, \mathrm{VII}, \mathrm{VIII}, \mathrm{X}$ & ATIII, PS, TFPI & $\mathrm{tPA} \uparrow, \mathrm{PAI}-1 \downarrow$ & & $\begin{array}{l}\text { Venous } \\
\text { thrombosis }\end{array}$ \\
\hline Diabetes mellitus & $\begin{array}{l}\text { TF, platelet, monocyte, } \\
\text { endothelial MP }\end{array}$ & $\begin{array}{l}\mathrm{Fg}, \mathrm{II}, \mathrm{V}, \mathrm{VII}, \mathrm{VIII} \text {, and } \\
\mathrm{X}\end{array}$ & $\begin{array}{l}\text { ATIII, PC, } \\
\text { endothelial TM }\end{array}$ & $\mathrm{PAl}-1 \uparrow, \mathrm{tPA} \uparrow$ & $\begin{array}{l}\text { Enhanced platelet adhesion, } \\
\text { aggregation, leukocyte activation, } \\
\text { WWF } \uparrow\end{array}$ & $\begin{array}{l}\text { Arterial } \\
\text { thrombosis, } \\
\text { Venous } \\
\text { thrombosis? }\end{array}$ \\
\hline
\end{tabular}


causes does not give an idea about overall tendency of the blood to form thrombi.

Another strategy is to use molecular markers of ongoing thrombosis: D-dimers, fibrinopeptides, soluble fibrin monomers, thrombin-antithrombin complexes or prothrombin fragments. This strategy is used widely and has tremendous clinical advantages, but its major drawback is that it detects traces of coagulation that already occurred or goes presently at full rate. In disseminated intravascular coagulation (DIC), you may have great $\mathrm{D}$-dimer in conjunction with zero clotting due to coagulopathy.

Finally, the natural way to determine hypercoagulation is to carry out coagulation experiments under conditions, where contribution of the hypercoagulation factors is significant (i.e. under conditions close in vivo). It turns out that it is not significant for the traditional clotting assays: when you stimulate clotting with huge concentrations of activators in APTT and PT, contribution of the small quantities of circulating active factors is not essential.

The possible solution to this might be global, or integral, assays of hemostasis [2-4]). They aim to mimic (patho)physiogical processes with greater accuracy and to involve all relevant processes, so they tend to determined overall hemostatic potential. Importantly, these assays usually involve low activator concentration (thrombin generation, TEG) or localization of the activator on the chamber wall (thrombodynamics, flow perfusion chambers). This could indeed make them sensitive to low concentrations of circulating agonists.

The purpose of the present review is to inventory the available data in order to test the existing claim of the global assays on their ability to predict thrombosis.

\section{APTT and INR: are they indeed inappropriate as global assays?}

Till the present times, initial evaluation of hemostatic status is done using APTT and INR assays. They are sensitive, first of all, to deficiencies of coagulation factors that usually result in their prolongation. Shortening of clot times is rare and is often attributed to pre-analytical errors (that play a great role in diagnostics, as it is very easy to induce hypercoagulation by insufficiently careful handling of whole blood). When dealing with thrombosis INR application is usually limited to assess the effectiveness of vitamin $\mathrm{K}$ doses [49].

However, there are reports that some thrombotic disorders may be detected by changes in APTT. Mina et al. demonstrated that APTT shortening reliably indicates abnormal factors V, XI, XII, VWF antigen and collagenbinding activity, and the level of procoagulant phospholipids, as assessed using a novel assay procedure (XACT) [50]. It is not clear whether factor VIII increase can shorten APTT. APTT shortening has also been associated with high levels of biochemical markers of thrombin generation and fibrin deposition such as prothrombin fragment 12, thrombin-antithrombin complex, and D-dimer [51]. Tripodi et al showed that shortened APTT is a risk factor for deep vein thrombosis. In patients who had an APTT ratio (coagulation time of test-to-reference plasma) smaller than the fifth percentile of the distribution in controls, the odds ratio (OR) for VTE was 2.4 and was independent of inherited thrombophilic abnormalities. Median APTT ratio values were 0.97 (range: 0.75-1.41) for patients and 1.00 (range: $0.72-1.33)$ for controls $(\mathrm{P}<.001)$ [52]. Prospective observation of a large group (918 patients) with spontaneous venous thrombosis revealed that APTT ratio was significantly longer in patients without thrombosis recurrence $(0.97 \pm 0.09$ vs. $0.93 \pm 0.09$, $\mathrm{P}<0.001)$ The relative risk (RR) of recurrence among patients with a APTT ratio or $<0.95$ was 1.7 [53]. Legnani et al. discovered that venous thrombosis recurrence risk after cancelling anticoagulation was more than twofold higher in patients with ratio $<$ or $=0.90$ versus those of the reference category (Relative risk (RR): 2.38) [54]. The data indicating predictive value of APTT are given in Table 2.

An important version of APTT is so-called clot waveform analysis that considers the entire optical density change curve, not only clot time. This assay is even included among the global assays [2-4]. In particular, two-phase curve in this assay is a sensitive and specific predictor of DIC ( $85 \%$ and $92 \%$, respectively) [56]. This curve is explained by precipitation of $\mathrm{C}$-reactive protein with VLDL upon addition of $\mathrm{Ca}$ [57].

So, it seems that APTT is working in some cases of pro-coagulant changes in plasma, but these successes are mostly associated with changes in the concentrations of coagulation factor components, not with appearance of coagulation-activating circulating material. It is most likely that potent artificial clotting activation in APTT (and even stronger activation in INR) does not allow observation of small effects produced by circulating TF, fXIa, or microparticles. Protein $\mathrm{C}$ pathway does not function in APTT unless activated protein $\mathrm{C}$ is added, but even then thrombin generation using the same approach is more sensitive [58]. APTT does not include fibrinolysis in any way. Probably that is why APTT has no predictive value as a thrombosis risk marker following surgery [59,60], trauma [61], diabetes [55,62], cancer [63]. Data about pregnancy are contradictive $[64,65]$. The main hypercoagulation factor detected by APTT shortening is most likely increased concentration or activity of coagulation factor predecessors. For example, in the study [54], increase of the recurrence risk of VT disappeared after adjustment for factor 
Table 2 Examples of APPT ratio response to different procoagulant states

\begin{tabular}{|c|c|c|c|c|c|c|c|}
\hline Procoagulant state & $\begin{array}{l}\text { Number of patients } \\
\text { in study group }\end{array}$ & $\begin{array}{l}\text { Data range in control } \\
\text { group, mean } \pm S D \\
\text { unless otherwise } \\
\text { indicated }\end{array}$ & $\begin{array}{l}\text { Data range in group } \\
\text { with hypercoagulation, } \\
\text { mean } \pm S D \text { unless } \\
\text { otherwise indicated }\end{array}$ & Significance & Predictive value & Reference & Comments \\
\hline VTE & 605 patients, 1290 - controls & $\begin{array}{l}\text { Median(range) } \\
1.00(0.72-1.33)\end{array}$ & $\begin{array}{l}\text { Median(range) } \\
0.97(0.75-1.41)\end{array}$ & $<0.001$ & APTT ratio $<0.87 \mathrm{OR}=2.4$ & {$[52]$} & Retrospective study. \\
\hline $\begin{array}{l}\text { Recurrence after first } \\
\text { unprovoked VTE }\end{array}$ & $\begin{array}{l}918 \text { with a first VTE } \\
101 \text { - with recurrence }\end{array}$ & $0.97 \pm 0.09$ & $0.93 \pm 0.09$ & 0.001 & APTT ratio $<0.95 \mathrm{RR}=1.79$ & [53] & $\begin{array}{l}\text { Prospective study. } \\
\text { Analysis was performed } \\
3 \text { weeks after after } \\
\text { completion of } \\
\text { anticoagulant therapy. }\end{array}$ \\
\hline $\begin{array}{l}\text { Recurrence after first } \\
\text { unprovoked VTE }\end{array}$ & $\begin{array}{l}628 \text { with a first VTE, } \\
71 \text { - with recurrence }\end{array}$ & & & & $\begin{array}{l}\text { APTT ratio }<0.90 \mathrm{RR}=2.38 \\
\text { compared with APTT } \\
\text { ratio }>1.05\end{array}$ & [54] & $\begin{array}{l}\text { Prospective study. } \\
\text { Analysis wasperformed } \\
3-4 \text { weeks after after } \\
\text { completion of } \\
\text { anticoagulant therapy. }\end{array}$ \\
\hline $\begin{array}{l}\text { Type } 2 \text { diabetes } \\
\text { mellitus }\end{array}$ & 60 patients, 57 controls & $\begin{array}{l}\text { Median(range) } 0.93 \\
(0.71-1.34)\end{array}$ & $\begin{array}{l}\text { Median(range) } 1.03 \\
(0.79-1.27)\end{array}$ & 0.43 & & {$[55]$} & \\
\hline
\end{tabular}


VIII, IX and XI levels, and coagulation factor levels themselves had better predictive capacity of recurrence risk $(\mathrm{RR}=2.38$ for $\mathrm{APTT}$ ratio $<0.90, \mathrm{RR}=3.01$; 3.06; 2.14 for increased levels of fVIII, dIX and fXI, respectively). Still, thrombophilic risk factors G1691Afactor V and G20210A-factor II did not differ significantly in groups with normal and shortened APTT [51].

\section{Hypercoagulation and thrombin generation}

Thrombin generation is one of the two best developed and tested global assays of hemostasis. Invented in its present form by the team of Coenraad Hemker of Maastricht University [66], the method uses a thrombinsensitive chromogenic or, recently, fluorogenic substrate. From the velocity of its cleavage, thrombin concentration as a function of time is obtained and used for diagnostic purposes; it usually has a characteristic bell-shape. Such parameters as endogenous thrombin potential (ETP, area under the thrombin generation curve) are among the most widely used, and their correlation with clinical phenotype is well established. Interestingly, most of the thrombin generation curve is observed after clot formation, and its meaning is still a subject of debate [67].

There are presently numerous modifications of thrombin generation including several commercially available versions. Typically, the assay is performed in platelet free plasma supplemented with phospholipids; use of platelet-rich plasma is also possible. Triggering is done by picomolar TF concentration, although other stimuli can be used. Thrombin generation experiments can be done with TM, protein C-activating enzymes or simply activated protein $\mathrm{C}$ to better highlight the protein $C$ pathway.

Tripodi et al. reported that patients with increased thrombin generation in the presence of TM have higher risk of recurrent venous thromboembolism. Those with ETP $>960 \mathrm{nM} \cdot \min$ or thrombin peak $>193 \mathrm{nM}$ had hazard ratios (HR) for recurrent VTE of 3.41 or 4.57 as compared with those with an ETP $<563 \mathrm{nM} \cdot \min$ or peak $<115 \mathrm{~nm}$. Patients with lag-time $<14.5 \mathrm{~min}$ had HR of 3.19 as compared with those with lag-time $>20.8 \mathrm{~min}$ [68]. The same was reported by Besser et al.: after adjustment for D-dimer, thrombophilia, sex, and whether or not the first event was unprovoked, a high ETP remained a significant predictor of recurrence, HR 2.6 [69]. In a similar study of Hron et al., patients without recurrent VTE had lower thrombin generation than patients with recurrence (mean [SD], 349.2 [108.0] nM vs 419.5 [110.5] nM, respectively; $\mathrm{P}<.001$ ). Compared with patients who had thrombin generation lower than 400 $\mathrm{nM}$, the relative risk (RR) of recurrence was 2.4 [70]. Interestingly, van Hylckama Vlieg et al. did not find any predictive value for thrombosis risk though this might be due to a different experimental design [71]. Chaireti et al. found, paradoxically, that ETP immediately after thrombosis is lower in the group of thrombosis recurrence. If blood was collected 1-2 months after cancellation of anticoagulants, their ETP was insignificantly higher [72].

Increased ETP in platelet-rich plasma was reported for patients after ischemic stroke [73]. In PPP, increased thrombin peak predicted stroke for women and did not correlated with stroke in men (hazard ratio 1.04 for men, 1.7 for women) [74]. ETP is increased in almost any thrombophilia including G20210A mutation [75], AT deficiency [76], factor V Leiden [77] and protein S deficiency [78] (if experiments are with thrombomodulin), upon oral contraceptive use [79], in cancer [80]. ETP is increased in pregnancy [81,82], but seems to reach a plateau in the first trimester [83], while D-dimer, F1 +2 and TAT increased, and there was no correlation between parameters of ETP assay and markers of in vivo thrombin generation. Lack of this correlation was confirmed in [80]. Patients with diabetes had significantly higher thrombin peak $[55,62]$, probably because of increased level of factors II, V, VII, VIII, and X and decreased protein $C$ [62].

Thrombin peak was reported to correlate with microparticle count, in particular when thrombin generation is performed without adding external activators and phospholipids [55]. Ollivier et al. found that lag time in recalcified plasma is sensitive to $\mathrm{TF}$ and does not affect the peak, while peak is sensitive to phospholipids. Distinct contributions of these two factors in cancer patients' plasmas were differentiated in [84]. Lipopolysaccharides reliably decreased lag time [85].

It appears that thrombin generation is sensitive to various hypercoagulation factors depending on the design: to levels of factors II, V, Fg, AT at high TF (13.6pM); to fXII, Fg, AT, free TFPI at low TF (1pM) [86], as well as to fVIII and fIX [87]; to protein C pathway defects upon addition of thrombomodulin or protein $\mathrm{C}$ activator [88]; to circulating TF when performed without activators; to lipids when performed without externally added lipids. Decrease of activation level increases overall sensitivity but increases deviation. Difference in the mean parameter values for patients with and without thrombosis is usually significant, but SDs usually overlap and it is complicated to transform such result into a clinical recommendation (Table 3). Although thrombin generation test standardization is presently under development [2] its lack restricts the method application.

Fibrinolysis and use of whole blood are currently beyond the available versions of this method, although some preliminary on thrombin generation in whole blood appeared [89]. There are no clinical data for thrombotic states for this version yet. 
Table 3 Examples of Trombin generation response to different procoagulant states

\begin{tabular}{|c|c|c|c|c|c|c|c|c|}
\hline $\begin{array}{l}\text { Procoagulant } \\
\text { state }\end{array}$ & $\begin{array}{l}\text { Number of } \\
\text { patients in } \\
\text { study group }\end{array}$ & $\begin{array}{l}\text { TG trigger and } \\
\text { additional } \\
\text { substances }\end{array}$ & $\begin{array}{l}\text { Data range in control } \\
\text { group, mean } \pm S D \\
\text { unless otherwise } \\
\text { indicated }\end{array}$ & $\begin{array}{l}\text { Data range in group } \\
\text { with hypercoagulation, } \\
\text { mean } \pm S D \text { unless } \\
\text { otherwise indicated }\end{array}$ & Significance & Predictive value & Reference & Comments \\
\hline \multirow{6}{*}{$\begin{array}{l}\text { Recurrence } \\
\text { after first } \\
\text { unprovoked } \\
\text { VTE }\end{array}$} & \multirow{6}{*}{$\begin{array}{l}254 \text { - with a } \\
\text { first VTE, } \\
34 \text { - with } \\
\text { recurrence }\end{array}$} & \multirow[t]{3}{*}{$\begin{array}{l}1 \mathrm{pM} \mathrm{TF} \\
1 \mathrm{UM} \mathrm{PL}\end{array}$} & $\begin{array}{l}\text { ETP, nM·min } \\
1502 \pm 446\end{array}$ & ETP, nM·min $1361 \pm 499$ & 0.122 & $\begin{array}{l}1 \text { tertile compared } \\
\text { to the } 3 \mathrm{HR}=2.54\end{array}$ & \multirow[t]{3}{*}[68]{} & \multirow{6}{*}{$\begin{array}{l}\text { Prospective study. } \\
\text { Analysis was performed } \\
2-3 \text { months after } \\
\text { completion of } \\
\text { anticoagulant } \\
\text { therapy. }\end{array}$} \\
\hline & & & Ila max, nM $232 \pm 82$ & Ila max, nM $187 \pm 89$ & 0.005 & $H R=3.09$ & & \\
\hline & & & Tlag, $\min 12 \pm 6$ & Tlag, $\min 13 \pm 5$ & 0.319 & $H R=2.29$ & & \\
\hline & & \multirow{3}{*}{$\begin{array}{l}1 \mathrm{pM} \text { TF } 1 \text { uM } \\
\text { PL } 4 \text { nM TM }\end{array}$} & $\mathrm{ETP}, \mathrm{nM} \cdot \min 986 \pm 422$ & $\mathrm{ETP}, \mathrm{nM} \cdot \min 763 \pm 468$ & 0.009 & $H R=3.35$ & \multirow[t]{3}{*}[68]{} & \\
\hline & & & Ila max, nM $201 \pm 75$ & Ila max, nM $148 \pm 88$ & $<0.001$ & $\mathrm{HR}=4.49$ & & \\
\hline & & & Tlag, $\min 17 \pm 7$ & Tlag, $\min 19 \pm 10$ & 0.174 & $H R=2.39$ & & \\
\hline \multirow[t]{2}{*}{$\begin{array}{l}\text { Unprovoked } \\
\text { recurrence } \\
\text { after first VTE }\end{array}$} & \multirow[t]{2}{*}{$\begin{array}{l}188 \text { with a } \\
\text { first VTE, } \\
29 \text { - with } \\
\text { recurrence }\end{array}$} & $\begin{array}{l}5 \mathrm{pM} \text { TF } 4 \text { uM } \\
\mathrm{PL}\end{array}$ & & & & $\begin{array}{l}\text { ETP }>50 \text { th } \\
\text { percentile } \\
H R=2.9\end{array}$ & {$[69]$} & \multirow[t]{2}{*}{$\begin{array}{l}\text { Prospective study. Analysis } \\
\text { was performed 2-3 months } \\
\text { after completion of } \\
\text { anticoagulant therapy. }\end{array}$} \\
\hline & & $\begin{array}{l}5 \text { pM TF } 4 \text { uM } \\
\text { PL 8nM TM }\end{array}$ & & & & $\begin{array}{l}\text { No significant } \\
\text { predictive value }\end{array}$ & {$[69]$} & \\
\hline $\begin{array}{l}\text { Recurrence } \\
\text { after first } \\
\text { unprovoked } \\
\text { VTE }\end{array}$ & $\begin{array}{l}914 \text { with a } \\
\text { first VTE, } 100 \text { - } \\
\text { with recurrence }\end{array}$ & $\begin{array}{l}72 \mathrm{pM} \mathrm{TF} \\
3.2 \mathrm{uM} \mathrm{PL}\end{array}$ & Ila max, nM $349 \pm 108$ & Ila max, nM 419 1110 & $<0.001$ & $\begin{array}{l}\text { Ila max }>400 \mathrm{nM} \\
\mathrm{RR}=2.5\end{array}$ & {$[70]$} & $\begin{array}{l}\text { Prospective study. } \\
\text { Analysis was performed } \\
\text { after completion of } \\
\text { anticoagulant therapy. }\end{array}$ \\
\hline \multirow[t]{3}{*}{$\begin{array}{l}\text { First and } \\
\text { recurrent VT }\end{array}$} & $\begin{array}{l}187 \text { with a first } \\
\text { unprovoked VT } \\
404 \text { controls }\end{array}$ & \multirow[t]{3}{*}{$\begin{array}{l}\text { 1/6 deluted } \\
\text { plasma } 2.5 \text { pM } \\
\text { TF } 4 \text { UM PL } 1.2 \\
\text { nM TM }\end{array}$} & $\begin{array}{l}\text { Mean ETP(95\% Cl), nM·min } \\
1641(1607-1676)\end{array}$ & $\begin{array}{l}\text { Mean ETP(95\% CI), } \\
\mathrm{nM} \cdot \min 1695(1639-1750)\end{array}$ & & $\begin{array}{l}\text { ETP }>\text { 90th } \\
\text { percentile } \\
\text { measured in } \\
\text { control subjects } \\
\text { DVT HR }=1.7\end{array}$ & {$[71]$} & \multirow[t]{3}{*}{$\begin{array}{l}\text { Analysis was performed } \\
3 \text { months after completion } \\
\text { of anticoagulant therapy. }\end{array}$} \\
\hline & $\begin{array}{l}173 \text { with a first } \\
\text { provoked VT } \\
404 \text { controls }\end{array}$ & & $\begin{array}{l}\text { Mean ETP(95\% CI), nM·min } \\
1641(1607-1676)\end{array}$ & $\begin{array}{l}\text { Mean ETP(95\% Cl), } \\
\mathrm{nM} \cdot \min 1649(1595-1703)\end{array}$ & & & {$[71]$} & \\
\hline & $\begin{array}{l}59 \text { recurrent } \\
\text { VTE }\end{array}$ & & & & & $\begin{array}{l}\text { HR of recurrence } \\
1.1\end{array}$ & {$[71]$} & \\
\hline \multirow{3}{*}{$\begin{array}{l}\text { Recurrence } \\
\text { after first } \\
\text { unprovoked } \\
\text { VTE }\end{array}$} & \multirow{3}{*}{$\begin{array}{l}105 \text { with a first } \\
\text { VTE, } 40 \text { - with } \\
\text { recurrence }\end{array}$} & \multirow{3}{*}{$\begin{array}{l}5 \mathrm{pM} \text { TF } 4 \text { uM } \\
\mathrm{PL}\end{array}$} & ETP, nM·min $1671 \pm 514$ & ETP, nM·min $1491 \pm 536$ & 0.111 & & \multirow[t]{3}{*}[72]{} & \multirow{3}{*}{$\begin{array}{l}\text { Prospective study. Analysis } \\
\text { was performed upon } \\
\text { diagnosis of VTE }\end{array}$} \\
\hline & & & Ila max, nM $302 \pm 91$ & Ila max, nM $261 \pm 125$ & 0.058 & & & \\
\hline & & & Tlag, $\min 7.2 \pm 2.2$ & Tlag, $\min 8.7 \pm 5$ & $<0.001$ & & & \\
\hline \multirow[t]{2}{*}{$\begin{array}{l}\text { Acute } \\
\text { Ischemic } \\
\text { Stroke (men) }\end{array}$} & \multirow[t]{2}{*}{$\begin{array}{l}42 \text { patients } 408 \\
\text { controls }\end{array}$} & \multirow[t]{2}{*}{$\begin{array}{l}5 \text { pM TF } 4 \text { uM } \\
\text { PL }\end{array}$} & $\begin{array}{l}\text { geometric mean and } \\
\text { interquartile range ETP, } \\
\text { nM.min } 1755 \text { (1620 - 1940) }\end{array}$ & $\begin{array}{l}\text { geometric mean and } \\
\text { interquartile range ETP, } \\
\text { nM·min } 1720(1572-1978)\end{array}$ & & $H R=0.88 / s d$ & \multirow[t]{2}{*}[74]{} & \multirow[t]{2}{*}{ Prospective study. } \\
\hline & & & $\begin{array}{l}\text { Ila max, nM } 327.0 \\
(304.9-357.8)\end{array}$ & $\begin{array}{l}\text { Ila max, nM } 330.2 \\
(301.8-361.4)\end{array}$ & & $H R=1.04 / s d$ & & \\
\hline $\begin{array}{l}\text { Acute } \\
\text { Ischemic }\end{array}$ & $\begin{array}{l}45 \text { patients } 666 \\
\text { controls }\end{array}$ & $\begin{array}{l}5 \mathrm{pM} \text { TF } 4 \text { uM } \\
\mathrm{PL}\end{array}$ & $\begin{array}{l}\text { ETP, nM·min } 1755 \\
(1604-1940)\end{array}$ & $\begin{array}{l}\text { ETP, nM-min } 1863 \\
(1636-1998)\end{array}$ & & $H R=1.55 / \mathrm{sd}$ & {$[74]$} & Prospective study \\
\hline
\end{tabular}


Table 3 Examples of Trombin generation response to different procoagulant states (Continued)

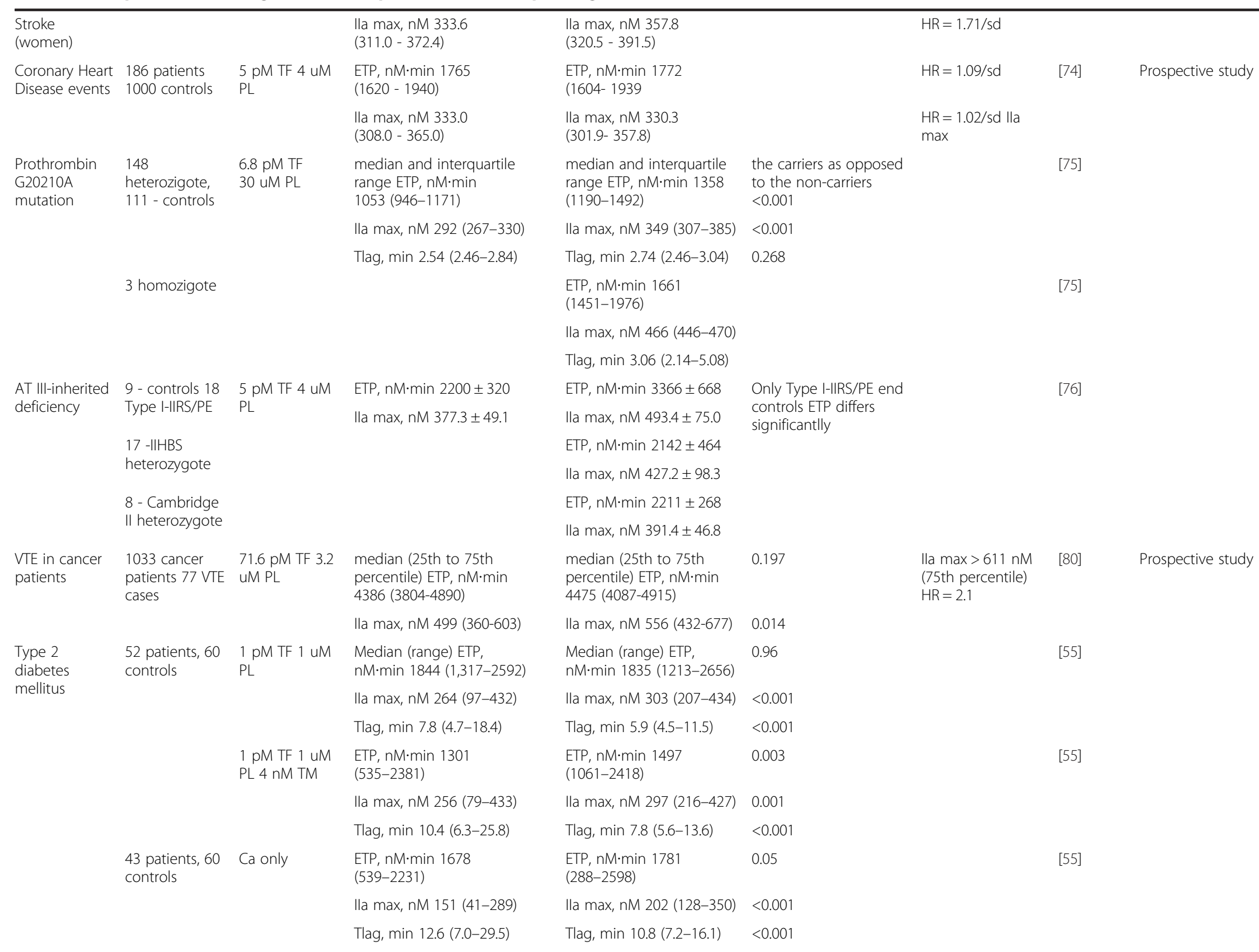


Table 3 Examples of Trombin generation response to different procoagulant states (Continued)

\begin{tabular}{|c|c|c|c|c|c|c|}
\hline \multirow[t]{3}{*}{$\begin{array}{l}\text { Diabetes } \\
\text { mellitus }\end{array}$} & \multirow[t]{3}{*}{$\begin{array}{l}89 \text { patients } \\
49 \text { controls }\end{array}$} & \multirow[t]{3}{*}{$\begin{array}{l}5 \mathrm{pM} \text { TF } 4 \text { uM } \\
\text { PL }\end{array}$} & ETP, nM·min $1566.4 \pm 240.7$ & $\begin{array}{l}\mathrm{ETP}, \mathrm{nM} \cdot \min 1876.5 \pm \\
390.0\end{array}$ & $<0.001$ & \multirow[t]{3}{*}{ [62] } \\
\hline & & & Ila max, nM $252.8 \pm 44.6$ & Ila max, nM $308.9 \pm 39.5$ & $<0.001$ & \\
\hline & & & Tlag, min $4.15 \pm 0.74$ & Tlag, min $3.59 \pm 0.62$ & $<0.001$ & \\
\hline \multirow[t]{6}{*}{$\begin{array}{l}\text { Normal } \\
\text { pregnancy }\end{array}$} & \multirow{6}{*}{$\begin{array}{l}19 \text { health } \\
\text { pregnant } \\
\text { women } 10 \\
\text { controls }\end{array}$} & \multirow{6}{*}{$\begin{array}{l}5 \mathrm{pM} \text { TF } 20 \mathrm{uM} \\
\text { PL } 0.1 \mathrm{mg} / \mathrm{ml} \\
\text { CTI }\end{array}$} & \multirow[t]{3}{*}{ ETP, nM·min $1553 \pm 567$} & $\begin{array}{l}\text { pre-pregnancy ETP, } \\
\mathrm{nM} \cdot \min 1162 \pm 446\end{array}$ & \multirow{6}{*}{$\begin{array}{l}\text { Significant difference } \\
\text { between pre-pregnancy } \\
\text { and early/late preg- } \\
\text { nancy } P<0.001\end{array}$} & \multirow[t]{6}{*}{ [82] } \\
\hline & & & & Ila max, nM $81 \pm 41$ & & \\
\hline & & & & $\begin{array}{l}\text { Early ETP, nM·min } 2157 \pm \\
466\end{array}$ & & \\
\hline & & & \multirow[t]{3}{*}{ Ila max, nM $159 \pm 100$} & Ila max, nM 219 1117 & & \\
\hline & & & & $\begin{array}{l}\text { Late ETP, nM·min } 2410 \pm \\
543\end{array}$ & & \\
\hline & & & & Ila max, nM $336 \pm 178$ & & \\
\hline \multirow{6}{*}{$\begin{array}{l}\text { Normal } \\
\text { pregnancy }\end{array}$} & \multirow{2}{*}{$\begin{array}{l}\text { 1st Trimester } \\
(n=36)\end{array}$} & \multirow{6}{*}{$\begin{array}{l}5 \mathrm{pM} \text { TF } 4 \text { uM } \\
\text { PL }\end{array}$} & \multirow{6}{*}{$\begin{array}{l}\text { TG on normal pooled } \\
\text { plasma was significantly } \\
\text { lower than TG on pregnant } \\
\text { women. The exact parameter's } \\
\text { values weren't shown }\end{array}$} & ETP, nM·min $2123 \pm 335$ & \multirow{6}{*}{$\begin{array}{l}\text { No significant } \\
\text { differences between } \\
\text { trimesters }\end{array}$} & \multirow[t]{6}{*}[83]{} \\
\hline & & & & Ila max, nM $366 \pm 43$ & & \\
\hline & \multirow{2}{*}{$\begin{array}{l}\text { 2nd Trimester } \\
(n=42)\end{array}$} & & & $E T P, n M \cdot \min 2067 \pm 326$ & & \\
\hline & & & & Ila max, nM $374 \pm 42$ & & \\
\hline & \multirow{2}{*}{$\begin{array}{l}\text { 3rd Trimester } \\
(n=23)\end{array}$} & & & ETP, nM·min $1915 \pm 261$ & & \\
\hline & & & & Ila max, nM $336 \pm 49$ & & \\
\hline
\end{tabular}




\section{Evaluation of thrombosis risk with TEG/ROTEM}

The most direct way to characterize clot formation is by rheometry, which has additional advantage of being independent of optical phenomena and easily applied in whole blood. There are numerous rheological approaches, and the best studied of them is thrombelastography. It is the most ancient global assay of hemostasis, where clot formation and platelet aggregation are evaluated simultaneously using forced oscillations rheometry.

Thrombelastography (TEG or ROTEM) has found a wide application for patients undergoing surgery as an alternative to APTT and INR that are not sensitive to hypercoagulation in this state $[59,90]$. A paper by Yue Dai et al. carefully examines reports between 1980 and 2008 about possibility to predict thrombosis using TEG, and majority of them answered positively. However, sensitivity and specificity varied between $0 \%-100 \%$ and $62 \%$ 92\% respectively, with odds ratio reported between 1.5 and 27.7 [91] thus preventing meta-analysis. Later reports confirmed predictive value of maximal amplitude (MA) and clot firmness G ( $\mathrm{G}=5000 \mathrm{MA} / 100-\mathrm{MA})$ as independent indicators of recurrent ischemic stroke after surgery $(\mathrm{OR}=1.192, \mathrm{p}=0.022)$ [92]; the same was obtained for other thrombotic complications Similar data were obtained for ROTEM [90]. MA is believed to be mostly dependent on platelet function and fibrinogen concentration [93]; this might explain why it does not correlate with APTT and INR [92].

TEG revealed hypercoagulation in patients with prostate cancer, in particular in the group with metastases, in agreement with the increase of TF-expressing microparticles. Thrombotic complications arose in 7 out of 22 patients with increased TEG, while APTT and INR were normal [63]. TEG was able to detect hypercoagulation in patients with breast and colorectal cancer [94], gastrointestinal system tumors, respiratory system tumors, and miscellaneous tumors [95], after DVT [96], but not after cerebral venous thrombosis [97]. TEG is increased only in 57\% patients with thrombophilia [98], this lack of sensitivity is confirmed in $[97,99]$. TEG reliably detect hypercoagulation in pregnancy that increases over the whole course [100-102] by parameters $r, \mathrm{~K}$, alfa, MA.

Like thrombin generation, thrombelastography is established to detect hypercoagulation, and there is evidence of both its shift in patient groups with known thrombotic risks and in patient groups with clinically occurring thrombosis. The pattern of sensitivity differs from that of thrombin generation: e.g., TEG is better in pregnancy but worse in thrombophilia. Still, wider use of this method suffers from the same shortcomings: deviations between donors are even greater that in thrombin generation resulting in poor difference between risks (Table 4), and there is lack of standardization.

\section{Novel assays}

There are several innovative global assays that are not used widely yet but may be promising as they include some really important aspects. Some of them are versions of the existing ones (e.g. there are numerous rheometric approaches beyond TEG [105]), while others use completely innovative principles. Below we discuss the methods that have been tested with regard to the prothrombotic sensitivity.

\section{Thrombin-and-plasmin generation}

There are several versions of the method to detect thrombin and plasmin at once [106-108]. Increased coagulation and impaired fibrinolysis are detected by means of overall hemostasis potential in patients with acquired arterial thrombotic events and vasculopathies, such as diabetic patients with microvascular complications, 15 patients with preeclampsia, 16 and elderly female patients with coronary heart disease [106]. Although the data are very scarce, this method is interesting as the only known alternative to TEG with regard to fibrinolysis evaluation.

\section{Thrombodynamics}

A novel strategy of blood coagulation testing is proposed in the thrombodynamics assay that has been developed and used as a research tool for almost two decades and became commercially available for clinical labs in 2012 . The central idea of the method is monitoring spatial fibrin formation initiated by immobilized tissue factor in plasma by videomicroscopy [109], so that clot is initially formed on the activator and then propagates into plasma. A version of the assay exists that can determine thrombin formation as a function of time and space in parallel with fibrin [110].

The idea behind this is to take into account spatial heterogeneity of blood coagulation, in other words, the fact that clotting initiation and propagation occurs in spatially separated regions [111]. In agreement with the wound clotting in vivo, tissue factor is located on the surface, and clot propagates because of coagulation factor activation and diffusion [112]. Importantly, separation of the activation and propagation phases makes the assay particularly sensitive to the presence of coagulation activators in plasma such as circulating tissue factor [112] or factor XIa [43]. Spatial clot formation velocity indicates overall procoagulant potential, while formation of activator-independent spontaneous clotting centers may indicate presence of microparticles and long-lived coagulation factors [43]. Pre-analytical standardization for this assay has also recently become available [113].

These biochemical findings have been confirmed by several preliminary studies. Hypercoagulation detected 


\section{Table 4 Examples of TEG response to different procoagulant states}

\begin{tabular}{|c|c|c|c|c|c|c|c|c|}
\hline $\begin{array}{l}\text { Procoagulant } \\
\text { state }\end{array}$ & $\begin{array}{l}\text { Number of patients in } \\
\text { study group }\end{array}$ & TEG version & $\begin{array}{l}\text { Data range in } \\
\text { control group, } \\
\text { mean } \pm \text { SD unless } \\
\text { otherwise } \\
\text { indicated }\end{array}$ & $\begin{array}{l}\text { Data range in group } \\
\text { with hypercoagulation, } \\
\text { mean } \pm \text { SD unless } \\
\text { otherwise indicated }\end{array}$ & Significance & Predictive value & Reference & Comments \\
\hline $\begin{array}{l}\text { Patients with } \\
\text { acute ischemic } \\
\text { stroke }\end{array}$ & $\begin{array}{l}\text { 93-Unfavorable outcome } \\
\text { evaluatewd by modified } \\
\text { Rankin Scale within a year } \\
\text { 91-Favorable outcome }\end{array}$ & $\begin{array}{l}\text { Citrate plasma was mixed } \\
\text { with kaolin, and loaded in } \\
\text { a heparinise-coated cup }\end{array}$ & $\begin{array}{l}\text { means } \pm \text { SE MA, } \\
\mathrm{mm} 63.2 \pm 0.5\end{array}$ & $\begin{array}{l}\text { means } \pm \text { SE MA, } \\
\mathrm{mm} \\
66.1 \pm 0.6\end{array}$ & $<0.001$ & $\begin{array}{l}\text { Prediction of unfavorable } \\
\text { outcome At higher tertile } \\
\text { of } \mathrm{MA} \mathrm{OR}=1.192\end{array}$ & [92] & Prospective study. \\
\hline \multirow[t]{2}{*}{$\begin{array}{l}\text { Postoperative } \\
\text { Thrombotic } \\
\text { Complications }\end{array}$} & $\begin{array}{l}240 \text { patients undergoing a } \\
\text { wide variety of surgical } \\
\text { procedure s, } 10 \text { thrombotic } \\
\text { complications }\end{array}$ & \multirow[t]{2}{*}{$\begin{array}{l}\text { celite-activated TEG on } \\
\text { native blood samples } \\
\text { within } 4 \text { min of collection }\end{array}$} & MA $66 \pm 9$ & $M A 71 \pm 9$ & & & \multirow[t]{2}{*}{ [103] } & \multirow[t]{8}{*}{$\begin{array}{l}\text { Prospective study. } \\
\text { Thromboelastography } \\
\text { was performed } \\
\text { immediately } \\
\text { after surgery. }\end{array}$} \\
\hline & 6 myocardial infarction & & MA $66 \pm 9$ & MA $74 \pm 5$ & & $\mathrm{OR}=1.16$ & & \\
\hline $\begin{array}{l}\text { Postoperative } \\
\text { Thrombotic } \\
\text { Complications }\end{array}$ & $\begin{array}{l}152 \text { critically ill patients in } \\
\text { the surgical intensive care } \\
\text { unit } 16 \text { thrombotic } \\
\text { complications }\end{array}$ & $\begin{array}{l}\text { native blood, rTEG } \\
\text { (activation with kaolin, } \\
\text { human recombinant TF, } \\
\text { phospholipids) }\end{array}$ & & & & $\begin{array}{l}\mathrm{G}>12.4 \text { dynes } / \mathrm{cm} \\
\mathrm{OR}=1.25\end{array}$ & [104] & \\
\hline \multirow{5}{*}{$\begin{array}{l}\text { Normal } \\
\text { pregnancy }\end{array}$} & \multirow[t]{5}{*}{$65 / 65$} & \multirow[t]{5}{*}{ Recalcified citrate plasma } & $R, \min 7.8 \pm 2.5$ & $R, \min 6.1 \pm 1.8$ & \multirow[t]{5}{*}{$<0.001$} & & \multirow[t]{5}{*}[102]{} & \\
\hline & & & $\mathrm{K}, \min 2.7 \pm 2.3$ & $\mathrm{~K}, \min 1.4 \pm 0.5$ & & & & \\
\hline & & & Alfa, deg $57.7 \pm 11.6$ & Alfa, deg $70.6 \pm 6.5$ & & & & \\
\hline & & & $\mathrm{MA}, \mathrm{mm} 61 \pm 5.9$ & $\mathrm{MA}, \mathrm{mm} 71 \pm 3.8$ & & & & \\
\hline & & & Ly $30, \% 0.8 \pm 1.7$ & Ly $30, \% 0.3 \pm 0.7$ & & & & \\
\hline
\end{tabular}


by thrombodynamics in patients with sepsis was confirmed by subsequent increase of D-dimers and occasional thrombosis [114]. Spontaneous clotting and increase spatial clot growth velocity were observed in patients with well-known thrombotic risks suffering from lymphomas, lymphogranulomatosis, thrombophilia, hemolytic anemia, acute leukemia, cardiac infarction [43]; the same was observed in a detailed study of multiple myeloma [115]. A case study demonstrated ability of thrombodynamics to detect hypercoagulation in betathalassemia [116]; portal vein thrombosis occurred after several weeks of increased clot growth velocity. In some of these papers, comparison was done with thrombin generation and thrombelastography, which did not show hypercoagulation changes in most cases.

To summarize, thrombodynamics assay shows significant promise as a tool to detect hypercoagulation and evaluate thrombotic risk, but additional clinical research is needed to establish a reliable relationship between assays indicators and thrombosis risks.

\section{Flow perfusion chambers}

Formation of platelets-and-fibrin thrombi in flow chambers observed by microscopy is potentially an "ultimate" global assay that is able to evaluate both platelet functions (including adhesion, aggregation, and procoagulant activity) and blood coagulation. Such microfluidic devices are being actively developed and used for various applications (see recent review in [116]). Review of this rapidly developing field is beyond the scope of the present paper. However, it should be noted that there are reports on the ability of flow perfusion chambers to detect hypercoagulation changes in blood [117-119]. However, there are few clinical studies and standardization status of these chambers is very poor [120]. Although theroretical consideration suggest significant potential of flow chambers, they have a long way to go in order to become a clinical tool.

\section{Conclusions}

The first conclusion of the present analysis is that the claim of the global assays that they can detect functional hypercoagulation is valid, to a significant degree. Compared with INR and APTT, sensitivity of the new global assays to hypercoagulation is definitely higher and encompasses a wider range of disorders and hypercoagulation causes. It is likely that there are two reasons behind this. First, these novel assays use smaller concentrations of activators, which do not obscure the effect of circulating pro-coagulant material (or, in some cases, activation and propagation phases are spatially separated). Second, the parameters provided by new global assays might be more sensitive than just time of clot formation, and involvement of all major reactions makes the assays sensitive to other pro-coagulant changes.

However, there are two major issues that complicate use of global assays for the evaluation of thrombotic risks.

The most important concern is that conclusion about sensitivity of the assays is usually reached with large patient cohorts only, standard deviations are large, and the differences of mean assay parameters between groups are significant mostly because of large statistics (Tables 2 , 3 and 4). In other words, if we attempt to define boundaries and select patient groups with different risks based on the assay parameters, the overall difference of thrombotic risk between groups is not usually large. It is questionable whether this difference is sufficient to affect clinical decisions. Some of the novel assays show promise of sensitivity increase, but their clinical utility also remains to be tested directly.

Another concern is lack of standardization. There are numerous versions for each assay, and clinical investigations often use different approaches, and the assay sensitivity strongly depends on the protocol used. Therefore, the results from different papers cited in this review might be difficult to interpret and to reproduce. The current attempts at standardization for some of the better established global assays such as thrombin generation [121-123]) make us hope that this might be resolved in the foreseeable future.

\section{Abbreviations}

APTT: Activated partial thromboplastin time; AT: Antithrombin; CP: Cancer procoagulant; DIC: Disseminated intravascular coagulation; DVT: Deep venous thrombosis; ETP: Endogenous thrombin potential; F1 + 2: Prothrombin activation fragments; HR: Hazard ratio; INR: International normalized ratio; MP: Microparticles; NET: Neutrophil extracellular traps; PAl-1: Plasminogen activator inhibitor type 1; PC: Protein C; PPP: Platelet poor plasma; PS: Protein S; PT: Prothrombin time; ROTEM: Rotational thromboelastometry; RR: Relative risk; TAT: Thrombin-antithrombin complex; TEG: Thromboelastography; TF: Tissue factor; TFPI: Tissue factor pathway inhibitor; TM: Thrombomodulin; tPA: Tissue plasminogen activator; VLDL: Very low density lipoproteins; VT: Venous thrombosis; VTE: Venous thromboembolism; vWF: Von Willebrand factor.

\section{Competing interest}

FA is an employee and a founder of HemaCore LLC that holds several patents on the use of spatial clot growth dynamics for blood clotting diagnostics, and develops the spatial clot growth assay under the trade name of Thrombodynamics.

\section{Authors' contributions}

EL collected and analyzed literature data, wrote the paper. FI wrote the paper, revised it critically, have given final approval of the version to be published. All authors read and approved the final manuscript.

\section{Acknowledgements}

The study was supported by the Russian Academy of Sciences Presidium Basic Research Programs 'Basic Research for Development of Biomedical Technologies', 'Molecular and Cellular Biology', 'Basic Science for Medicine' and 'Integrative Physiology', and by the Russian Foundation for Basic Research grants 14-04-00670, 13-04-00401 and 12-04-00438. E.N.L. gratefully acknowledges support of her work on contact activation from Russian Science Foundation grant 14-14-00195. 


\section{Author details}

${ }^{1}$ Center for Theoretical Problems of Physicochemical Pharmacology, Russian Academy of Sciences, Moscow, Russia. ${ }^{2}$ National Research Center for Hematology, Moscow, Russia. ${ }^{3}$ Physics Department, Moscow State University, Moscow, Russia. ${ }^{4}$ Federal Research and Clinical Center of Pediatric Hematology, Oncology and Immunology, Moscow, Russia. ${ }^{5}$ Faculty of Biological and Medical Physics, Moscow Institute of Physics and Technology, Dolgoprudny, Russia. ${ }^{6}$ HemaCore LLC, Moscow, Russia.

\section{Received: 29 October 2014 Accepted: 12 January 2015}

\section{Published online: 23 January 2015}

\section{References}

1. Sinauridze El, Panteleev MA, Ataullakhanov Fl. Anticoagulant therapy: basic principles, classic approaches and recent developments. Blood Coagul Fibrinolysis. 2012;23:482-93.

2. Brummel-Ziedins KE, Wolberg AS. Global assays of hemostasis. Curr Opin Hematol. 2014;21:395-403.

3. van Geffen M, van Heerde WL. Global haemostasis assays, from bench to bedside. Thromb Res. 2012;129:681-7.

4. Dargaud Y, Sorensen B, Shima M, Hayward C, Srivastava A, Negrier C. Global haemostasis and point of care testing. Haemophilia. 2012;18 Suppl 4:81-8.

5. Lopez JA, Chen J. Pathophysiology of venous thrombosis. Thromb Res. 2009:123 Suppl 4:S30-4.

6. Lopez JA, Kearon C, Lee AY. Deep venous thrombosis. Hematology Am Soc Hematol Educ Program 2004(1):439-456.

7. Friedman MH, Brinkman AM, Qin JJ, Seed WA. Relation between coronary artery geometry and the distribution of early sudanophilic lesions. Atherosclerosis. 1993;98:193-9.

8. Sevitt $\mathrm{S}$. The structure and growth of valve-pocket thrombi in femoral veins. J Clin Pathol. 1974;27:517-28.

9. von Bruhl ML, Stark K, Steinhart A, Chandraratne S, Konrad I, Lorenz M, et al. Monocytes, neutrophils, and platelets cooperate to initiate and propagate venous thrombosis in mice in vivo. J Exp Med. 2012;209:819-35.

10. Lawson CA, Yan SD, Yan SF, Liao H, Zhou YS, Sobel J, et al. Monocytes and tissue factor promote thrombosis in a murine model of oxygen deprivation. J Clin Invest. 1997;99:1729-38.

11. Lacroix R, Dubois C, Leroyer AS, Sabatier F, Dignat-George F. Revisited role of microparticles in arterial and venous thrombosis. J Thromb Haemost. 2013;11 Suppl 1:24-35.

12. Van Der Meijden PE, Van Schilfgaarde M, Van Oerle R, Renne T, ten Cate H, Spronk HM. Platelet- and erythrocyte-derived microparticles trigger thrombin generation via factor Xlla. J Thromb Haemost. 2012;10:1355-62.

13. Shibeko AM, Lobanova ES, Panteleev MA, Ataullakhanov FI. Blood flow controls coagulation onset via the positive feedback of factor VII activation by factor Xa. BMC Syst Biol. 2010;4:5.

14. Tokarev AA, Butylin AA, Ataullakhanov FI. Platelet adhesion from shear blood flow is controlled by near-wall rebounding collisions with erythrocytes. Biophys J. 2011;100:799-808.

15. Davi G, Patrono C. Platelet activation and atherothrombosis. N Engl J Med. 2007;357:2482-94.

16. Sonneveld MA, de Maat MP, Leebeek FW. Von Willebrand factor and ADAMTS13 in arterial thrombosis: a systematic review and meta-analysis. Blood Rev. 2014;28:167-78.

17. Kubisz P, Ruiz-Arguelles GJ, Stasko J, Holly P, Ruiz-Delgado GJ. Sticky platelet syndrome: history and future perspectives. Semin Thromb Hemost. 2014;40:526-34

18. Undas A, Slowik A, Gissel M, Mann KG, Butenas S. Circulating activated factor XI and active tissue factor as predictors of worse prognosis in patients following ischemic cerebrovascular events. Thromb Res. 2011;128:e62-6.

19. Zabczyk M, Butenas S, Plicner D, Fijorek K, Sadowski J, Undas A. Factors associated with the presence of circulating active tissue factor and activated factor $\mathrm{XI}$ in stable angina patients. Blood Coagul Fibrinolysis. 2012;23:189-94.

20. Zabczyk M, Butenas S, Palka I, Nessler J, Undas A. Active tissue factor and activated factor $\mathrm{XI}$ in circulating blood of patients with systolic heart failure due to ischemic cardiomyopathy. Pol Arch Med Wewn. 2010;120:334-40.

21. Weitz Jl. Insights into the role of thrombin in the pathogenesis of recurrent ischaemia after acute coronary syndrome. Thromb Haemost. 2014;112(5):924-31.
22. Kwaan HC. Microvascular thrombosis: a serious and deadly pathologic process in multiple diseases. Semin Thromb Hemost. 2011;37:961-78.

23. Bellido-Martin L, Chen V, Jasuja R, Furie B, Furie BC. Imaging fibrin formation and platelet and endothelial cell activation in vivo. Thromb Haemost. 2011;105:776-82.

24. Pfeiler S, Massberg S, Engelmann B. Biological basis and pathological relevance of microvascular thrombosis. Thromb Res. 2014;133 Suppl 1:S35-7.

25. Levi M, Schultz M, van der Poll T. Sepsis and thrombosis. Semin Thromb Hemost. 2013;39:559-66.

26. Langer F, Bokemeyer C. Crosstalk between cancer and haemostasis. Implications for cancer biology and cancer-associated thrombosis with focus on tissue factor. Hamostaseologie. 2012;32:95-104.

27. Barrabes JA, Inserte J, Agullo L, Alonso A, Mirabet M, Garcia-Dorado D. Microvascular thrombosis: an exciting but elusive therapeutic target in reperfused acute myocardial infarction. Cardiovasc Hematol Disord Drug Targets. 2010;10:273-83.

28. Blake-Haskins JA, Lechleider RJ, Kreitman RJ. Thrombotic microangiopathy with targeted cancer agents. Clin Cancer Res. 2011;17:5858-66.

29. Gando S. Microvascular thrombosis and multiple organ dysfunction syndrome. Crit Care Med. 2010;38:S35-42.

30. Semeraro N, Ammollo CT, Semeraro F, Colucci M. Sepsis, thrombosis and organ dysfunction. Thromb Res. 2012;129:290-5.

31. Yu JL, May L, Lhotak V, Shahrzad S, Shirasawa S, Weitz Jl, et al. Oncogenic events regulate tissue factor expression in colorectal cancer cells: implications for tumor progression and angiogenesis. Blood. 2005;105:1734-41.

32. Geddings JE, Mackman N. Tumor-derived tissue factor-positive microparticles and venous thrombosis in cancer patients. Blood. 2013;122:1873-80.

33. Tesselaar ME, Romijn FP, Van Der Linden IK, Prins FA, Bertina RM, Osanto S. Microparticle-associated tissue factor activity: a link between cancer and thrombosis? J Thromb Haemost. 2007;5:520-7.

34. Levi M. Cancer and thrombosis. Clin Adv Hematol Oncol. 2003;1:668-71.

35. Demers M, Wagner DD. Neutrophil extracellular traps: A new link to cancerassociated thrombosis and potential implications for tumor progression. Oncoimmunology. 2013;2:e22946.

36. Wahrenbrock M, Borsig L, Le D, Varki N, Varki A. Selectin-mucin interactions as a probable molecular explanation for the association of Trousseau syndrome with mucinous adenocarcinomas. J Clin Invest. 2003;112:853-62.

37. Bremme KA. Haemostatic changes in pregnancy. Best Pract Res Clin Haematol. 2003:16:153-68.

38. Medcalf RL, Stasinopoulos SJ. The undecided serpin. The ins and outs of plasminogen activator inhibitor type 2. Febs J. 2005;272:4858-67.

39. Alijotas-Reig J, Palacio-Garcia C, Llurba E, Vilardell-Tarres M. Cell-derived microparticles and vascular pregnancy complications: a systematic and comprehensive review. Fertil Steril. 2013;99:441-9.

40. Patil R, Ghosh K, Satoskar P, Shetty S. Elevated procoagulant endothelial and tissue factor expressing microparticles in women with recurrent pregnancy loss. PLoS One. 2013;8:e81407.

41. Sandset PM. Mechanisms of hormonal therapy related thrombosis. Thromb Res. 2013;131 Suppl 1:S4-7.

42. Morel $\mathrm{O}$, Jesel $\mathrm{L}$, Abbas M, Morel N. Prothrombotic changes in diabetes mellitus. Semin Thromb Hemost. 2013;39:477-88.

43. Lipets E, Vlasova O, Urnova E, Margolin O, Soloveva A, Ostapushchenko O, et al. Circulating contact-pathway-activating microparticles together with factors IXa and Xla induce spontaneous clotting in plasma of hematology and cardiologic patients. PLoS One. 2014;9:e87692.

44. Poort SR, Rosendaal FR, Reitsma PH, Bertina RM. A common genetic variation in the $3^{\prime}$-untranslated region of the prothrombin gene is associated with elevated plasma prothrombin levels and an increase in venous thrombosis. Blood. 1996:88:3698-703.

45. Lindahl TL, Lundahl TH, Nilsson L, Andersson CA. APC-resistance is a risk factor for postoperative thromboembolism in elective replacement of the hip or knee-a prospective study. Thromb Haemost. 1999;81:18-21.

46. Rosendaal FR, Koster T, Vandenbroucke JP, Reitsma PH. High risk of thrombosis in patients homozygous for factor $V$ Leiden (activated protein C resistance). Blood. 1995:85:1504-8.

47. Lijfering WM, Brouwer JL, Veeger NJ, Bank I, Coppens M, Middeldorp S, et al. Selective testing for thrombophilia in patients with first venous thrombosis: results from a retrospective family cohort study on absolute thrombotic risk for currently known thrombophilic defects in 2479 relatives. Blood. 2009;113:5314-22 
48. Koster T, Rosendaal FR, Briet E, van der Meer FJ, Colly LP, Trienekens PH, et al. Protein $C$ deficiency in a controlled series of unselected outpatients: an infrequent but clear risk factor for venous thrombosis (Leiden Thrombophilia Study). Blood. 1995;85:2756-61.

49. Levy JH, Szlam F, Wolberg AS, Winkler A. Clinical use of the activated partial thromboplastin time and prothrombin time for screening: a review of the literature and current guidelines for testing. Clin Lab Med. 2014;34:453-77.

50. Mina A, Favaloro EJ, Mohammed S, Koutts J. A laboratory evaluation into the short activated partial thromboplastin time. Blood Coagul Fibrinolysis. 2010;21:152-7.

51. Ten Boekel E, Bartels P. Abnormally short activated partial thromboplastin times are related to elevated plasma levels of TAT, F1 + 2, D-dimer and FVIII: C. Pathophysiol Haemost Thromb. 2002;32:137-42.

52. Tripodi A, Chantarangkul V, Martinelli I, Bucciarelli P, Mannucci PM. A shortened activated partial thromboplastin time is associated with the risk of venous thromboembolism. Blood. 2004;104:3631-4.

53. Hron G, Eichinger S, Weltermann A, Quehenberger P, Halbmayer WM, Kyrle PA. Prediction of recurrent venous thromboembolism by the activated partial thromboplastin time. J Thromb Haemost. 2006;4:752-6.

54. Legnani C, Mattarozzi S, Cini M, Cosmi B, Favaretto E, Palareti G. Abnormally short activated partial thromboplastin time values are associated with increased risk of recurrence of venous thromboembolism after oral anticoagulation withdrawal. Br J Haematol. 2006;134:227-32.

55. Tripodi A, Branchi A, Chantarangkul V, Clerici M, Merati G, Artoni A, et al. Hypercoagulability in patients with type 2 diabetes mellitus detected by a thrombin generation assay. J Thromb Thrombolysis. 2011;31:165-72.

56. Hussain N, Hodson D, Marcus R, Baglin T, Luddington R. The biphasic transmittance waveform: an early marker of sepsis in patients with neutropenia. Thromb Haemost. 2008;100:146-8.

57. Toh CH, Samis J, Downey C, Walker J, Becker L, Brufatto N, et al. Biphasic transmittance waveform in the APTT coagulation assay is due to the formation of a $\mathrm{Ca}(++)$-dependent complex of $\mathrm{C}$-reactive protein with verylow-density lipoprotein and is a novel marker of impending disseminated intravascular coagulation. Blood. 2002;100:2522-9.

58. Curvers J, Thomassen MC, Nicolaes GA, Van Oerle R, Hamulyak K, Hemker $\mathrm{HC}$, et al. Acquired APC resistance and oral contraceptives: differences between two functional tests. Br J Haematol. 1999;105:88-94.

59. Park MS, Martini WZ, Dubick MA, Salinas J, Butenas S, Kheirabadi BS, et al. Thromboelastography as a better indicator of hypercoagulable state after injury than prothrombin time or activated partial thromboplastin time. J Trauma. 2009;67:266-75. discussion 275-266.

60. Schreiber MA, Differding J, Thorborg P, Mayberry JC, Mullins RJ. Hypercoagulability is most prevalent early after injury and in female patients. J Trauma. 2005;58:475-80. discussion 480-471.

61. Kaufmann CR, Dwyer KM, Crews JD, Dols SJ, Trask AL. Usefulness of thrombelastography in assessment of trauma patient coagulation. J Trauma. 1997;42:716-20. discussion 720-712.

62. Kim HK, Kim JE, Park SH, Kim Yl, Nam-Goong IS, Kim ES. High coagulation factor levels and low protein $C$ levels contribute to enhanced thrombin generation in patients with diabetes who do not have macrovascular complications. J Diabetes Complications. 2014;28:365-9.

63. Toukh M, Siemens DR, Black A, Robb S, Leveridge M, Graham CH, et al. Thromboelastography identifies hypercoagulability and predicts thromboembolic complications in patients with prostate cancer. Thromb Res. 2014;133:88-95.

64. Othman M, Falcon BJ, Kadir R. Global hemostasis in pregnancy: are we using thromboelastography to its full potential? Semin Thromb Hemost. 2010;36:738-46.

65. Hammerova L, Chabada J, Drobny J, Batorova A. Longitudinal evaluation of markers of hemostasis in pregnancy. Bratisl Lek Listy. 2014;115:140-4.

66. Hemker HC, Wielders S, Kessels H, Beguin S. Continuous registration of thrombin generation in plasma, its use for the determination of the thrombin potential. Thromb Haemost. 1993;70:617-24.

67. Mann KG, Brummel K, Butenas S. What is all that thrombin for? J Thromb Haemost. 2003;1:1504-14.

68. Tripodi A, Legnani C, Chantarangkul V, Cosmi B, Palareti G, Mannucci PM High thrombin generation measured in the presence of thrombomodulin is associated with an increased risk of recurrent venous thromboembolism. J Thromb Haemost. 2008;6:1327-33.

69. Besser M, Baglin C, Luddington R, van Hylckama VA, Baglin T. High rate of unprovoked recurrent venous thrombosis is associated with high thrombin- generating potential in a prospective cohort study. J Thromb Haemost. 2008;6:1720-5.

70. Hron G, Kollars M, Binder BR, Eichinger S, Kyrle PA. Identification of patients at low risk for recurrent venous thromboembolism by measuring thrombin generation. Jama. 2006;296:397-402.

71. van Hylckama VA, Christiansen SC, Luddington R, Cannegieter SC, Rosendaal FR, Baglin TP. Elevated endogenous thrombin potential is associated with an increased risk of a first deep venous thrombosis but not with the risk of recurrence. Br J Haematol. 2007;138:769-74.

72. Chaireti $\mathrm{R}$, Jennersjo $\mathrm{C}$, Lindahl $\mathrm{TL}$. Is thrombin generation at the time of an acute thromboembolic episode a predictor of recurrence? The LInkoping Study on Thrombosis (LIST)-a 7-year follow-up. Thromb Res. 2013;131:135-9.

73. Faber CG, Lodder J, Kessels F, Troost J. Thrombin generation in platelet-rich plasma as a tool for the detection of hypercoagulability in young stroke patients. Pathophysiol Haemost Thromb. 2003;33:52-8.

74. Carcaillon L, Alhenc-Gelas M, Bejot Y, Spaft C, Ducimetiere P, Ritchie K, et al. Increased thrombin generation is associated with acute ischemic stroke but not with coronary heart disease in the elderly: the Three-City cohort study. Arterioscler Thromb Vasc Biol. 2011;31:1445-51.

75. Castoldi E, Simioni P, Tormene D, Thomassen MC, Spiezia L, Gavasso S, et al. Differential effects of high prothrombin levels on thrombin generation depending on the cause of the hyperprothrombinemia. J Thromb Haemost. 2007:5:971-9.

76. Alhenc-Gelas M, Canonico M, Picard V. Influence of natural SERPINC1 mutations on ex vivo thrombin generation. J Thromb Haemost. 2010;8:845-8.

77. Simioni P, Castoldi E, Lunghi B, Tormene D, Rosing J, Bernardi F. An underestimated combination of opposites resulting in enhanced thrombotic tendency. Blood. 2005;106:2363-5.

78. Castoldi E, Maurissen LF, Tormene D, Spiezia L, Gavasso S, Radu C, et al. Similar hypercoagulable state and thrombosis risk in type I and type III protein S-deficient individuals from families with mixed type I/III protein S deficiency. Haematologica. 2010;95:1563-71.

79. Tchaikovski SN, van Vliet HA, Thomassen MC, Bertina RM, Rosendaal FR, Sandset PM, et al. Effect of oral contraceptives on thrombin generation measured via calibrated automated thrombography. Thromb Haemost. 2007;98:1350-6.

80. Ay C, Dunkler D, Simanek R, Thaler J, Koder S, Marosi C, et al. Prediction of venous thromboembolism in patients with cancer by measuring thrombin generation: results from the Vienna Cancer and Thrombosis Study. J Clin Oncol. 2011;29:2099-103.

81. Rosenkranz A, Hiden M, Leschnik B, Weiss EC, Schlembach D, Lang U, et al. Calibrated automated thrombin generation in normal uncomplicated pregnancy. Thromb Haemost. 2008;99:331-7.

82. McLean KC, Bernstein IM, Brummel-Ziedins KE. Tissue factor-dependent thrombin generation across pregnancy. Am J Obstet Gynecol. 2012;207(135):e131-6.

83. Joly B, Barbay V, Borg JY, Le Cam-Duchez V. Comparison of markers of coagulation activation and thrombin generation test in uncomplicated pregnancies. Thromb Res. 2013;132:386-91.

84. Debaugnies F, Azerad MA, Noubouossie D, Rozen L, Hemker HC, Corazza F, et al. Evaluation of the procoagulant activity in the plasma of cancer patients using a thrombin generation assay. Thromb Res. 2010;126:531-5.

85. Ollivier $V$, Wang J, Manly D, Machlus KR, Wolberg AS, Jandrot-Perrus M, et al. Detection of endogenous tissue factor levels in plasma using the calibrated automated thrombogram assay. Thromb Res. 2010;125:90-6.

86. Dielis AW, Castoldi E, Spronk HM, van Oerle R, Hamulyak K, Ten Cate H, et al. Coagulation factors and the protein $C$ system as determinants of thrombin generation in a normal population. J Thromb Haemost. 2008;6:125-31.

87. van Veen JJ, Gatt A, Cooper PC, Kitchen S, Bowyer AE, Makris M. Corn trypsin inhibitor in fluorogenic thrombin-generation measurements is only necessary at low tissue factor concentrations and influences the relationship between factor VIII coagulant activity and thrombogram parameters. Blood Coagul Fibrinolysis. 2008;19:183-9.

88. Dargaud Y, Trzeciak MC, Bordet JC, Ninet J, Negrier C. Use of calibrated automated thrombinography $+/$ - thrombomodulin to recognise the prothrombotic phenotype. Thromb Haemost. 2006;96:562-7.

89. Ninivaggi M, Apitz-Castro R, Dargaud Y, de Laat B, Hemker HC, Lindhout T. Whole-blood thrombin generation monitored with a calibrated automated thrombogram-based assay. Clin Chem. 2012;58:1252-9.

90. Hincker A, Feit J, Sladen RN, Wagener G. Rotational thromboelastometry predicts thromboembolic complications after major non-cardiac surgery. Crit Care. 2014;18:549. 
91. Dai Y, Lee A, Critchley LA, White PF. Does thromboelastography predict postoperative thromboembolic events? A systematic review of the literature. Anesth Analg. 2009;108:734-42.

92. Yao X, Dong Q, Song Y, Wang Y, Deng Y, Li Y. Thrombelastography Maximal Clot Strength Could Predict One-Year Functional Outcome in Patients with Ischemic Stroke. Cerebrovasc Dis. 2014;38:182-90.

93. Kang YG, Martin DJ, Marquez J, Lewis JH, Bontempo FA, Shaw Jr BW, et al. Intraoperative changes in blood coagulation and thrombelastographic monitoring in liver transplantation. Anesth Analg. 1985;64:888-96.

94. Francis JL, Francis DA, Gunathilagan GJ. Assessment of hypercoagulability in patients with cancer using the Sonoclot Analyzer and thromboelastography. Thromb Res. 1994;74:335-46.

95. Akay OM, Ustuner Z, Canturk Z, Mutlu FS, Gulbas Z. Laboratory investigation of hypercoagulability in cancer patients using rotation thrombelastography. Med Oncol. 2009;26:358-64.

96. Spiezia L, Marchioro P, Radu C, Rossetto V, Tognin G, Monica C, et al. Whole blood coagulation assessment using rotation thrombelastogram thromboelastometry in patients with acute deep vein thrombosis. Blood Coagul Fibrinolysis. 2008;19:355-60.

97. Koopman K, Uyttenboogaart M, Hendriks HG, Luijckx GJ, Cramwinckel IR, Vroomen PC, et al. Thromboelastography in patients with cerebral venous thrombosis. Thromb Res. 2009;124:185-8.

98. O'Donnell J, Riddell A, Owens D, Handa A, Pasi J, Hamilton G, et al. Role of the Thrombelastograph as an adjunctive test in thrombophilia screening. Blood Coagul Fibrinolysis. 2004;15:207-11.

99. Miall FM, Deol PS, Barnes TA, Dampier K, Watson CC, Oppenheimer CA, et al. Coagulation status and complications of pregnancy. Thromb Res. 2005;115:461-7.

100. Sharma SK, Philip J, Wiley J. Thromboelastographic changes in healthy parturients and postpartum women. Anesth Analg. 1997:85:94-8.

101. Steer PL, Krantz HB. Thromboelastography and Sonoclot analysis in the healthy parturient. J Clin Anesth. 1993;5:419-24.

102. Della Rocca G, Dogareschi T, Cecconet T, Buttera S, Spasiano A, Nadbath P, et al. Coagulation assessment in normal pregnancy: thrombelastography with citrated non activated samples. Minerva Anestesiol. 2012;78:1357-64.

103. McCrath DJ, Cerboni E, Frumento RJ, Hirsh AL, Bennett-Guerrero E. Thromboelastography maximum amplitude predicts postoperative thrombotic complications including myocardial infarction. Anesth Analg. 2005;100:1576-83.

104. Kashuk JL, Moore EE, Sabel A, Barnett C, Haenel J, Le T, et al. Rapid thrombelastography ( $r$-TEG) identifies hypercoagulability and predicts thromboembolic events in surgical patients. Surgery. 2009;146:764-72. discussion 772-764.

105. Evans PA, Hawkins K, Lawrence M, Williams RL, Barrow MS, Thirumalai N, et al. Rheometry and associated techniques for blood coagulation studies. Med Eng Phys. 2008;30:671-9.

106. Antovic A. The overall hemostasis potential: a laboratory tool for the investigation of global hemostasis. Semin Thromb Hemost. 2010;36:772-9.

107. Simpson ML, Goldenberg NA, Jacobson LJ, Bombardier CG, Hathaway WE, Manco-Johnson MJ. Simultaneous thrombin and plasmin generation capacities in normal and abnormal states of coagulation and fibrinolysis in children and adults. Thromb Res. 2011;127:317-23.

108. Matsumoto T, Nogami K, Shima M. Simultaneous measurement of thrombin and plasmin generation to assess the interplay between coagulation and fibrinolysis. Thromb Haemost. 2013;110:761-8.

109. Fadeeva OA, Panteleev MA, Karamzin SS, Balandina AN, Smirnov IV, Ataullakhanov FI. Thromboplastin immobilized on polystyrene surface exhibits kinetic characteristics close to those for the native protein and activates in vitro blood coagulation similarly to thromboplastin on fibroblasts. Biochemistry (Mosc). 2010;75:734-43.

110. Dashkevich NM, Ovanesov MV, Balandina AN, Karamzin SS, Shestakov PI, Soshitova NP, et al. Thrombin activity propagates in space during blood coagulation as an excitation wave. Biophys J. 2012;103:2233-40.

111. Ovanesov MV, Ananyeva NM, Panteleev MA, Ataullakhanov FI, Saenko EL. Initiation and propagation of coagulation from tissue factor-bearing cell monolayers to plasma: initiator cells do not regulate spatial growth rate. J Thromb Haemost. 2005;3:321-31.

112. Panteleev MA, Ovanesov MV, Kireev DA, Shibeko AM, Sinauridze El, Ananyeva NM, et al. Spatial propagation and localization of blood coagulation are regulated by intrinsic and protein $C$ pathways, respectively. Biophys J. 2006;90:1489-500.
113. Dashkevich NM, Vuimo TA, Ovsepyan RA, Surov SS, Soshitova NP, Panteleev MA, et al. Effect of pre-analytical conditions on the thrombodynamics assay. Thromb Res. 2014;133:472-6.

114. Soshitova NP, Karamzin SS, Balandina AN, Fadeeva OA, Kretchetova AV Galstian GM, et al. Predicting prothrombotic tendencies in sepsis using spatial clot growth dynamics. Blood Coagul Fibrinolysis. 2012;23:498-507.

115. Urnova ES, Pokrovskaia OS, Gracheva MA, Vasil'ev SA, Gemdzhian EG, Tarandovskii ID, et al. [Hypercoagulation syndrome in multiple myeloma] Ter Arkh. 2014;86:73-9.

116. Seregina EA, Nikulina OF, Tsvetaeva NV, Rodionova MN, Gribkova IV, Orel EB, et al. Laboratory tests for coagulation system monitoring in a patient with beta-thalassemia. Int J Hematol. 2014;99:588-96.

117. Gorog DA, Kovacs IB. Thrombotic status analyser. Measurement of platelet-rich thrombus formation and lysis in native blood. Thromb Haemost. 1995;73:514-20.

118. Suades R, Padro T, Vilahur G, Badimon L. Circulating and platelet-derived microparticles in human blood enhance thrombosis on atherosclerotic plaques. Thromb Haemost. 2012;108:1208-19.

119. Shechter M, Merz CN, Paul-Labrador MJ, Kaul S. Blood glucose and platelet-dependent thrombosis in patients with coronary artery disease. J Am Coll Cardiol. 2000;35:300-7.

120. Roest M, Reininger A, Zwaginga JJ, King MR, Heemskerk JW. Flow chamberbased assays to measure thrombus formation in vitro: requirements for standardization. J Thromb Haemost. 2011;9:2322-4

121. Woodle SA, Shibeko AM, Lee TK, Ovanesov MV. Determining the impact of instrument variation and automated software algorithms on the TGT in hemophilia and normalized plasma. Thromb Res. 2013;132:374-80.

122. Loeffen $R$, Kleinegris MC, Loubele ST, Pluijmen PH, Fens D, van Oerle R, et al. Preanalytic variables of thrombin generation: towards a standard procedure and validation of the method. J Thromb Haemost. 2012;10:2544-54.

123. Dargaud Y, Wolberg AS, Luddington R, Regnault V, Spronk H, Baglin T, et al. Evaluation of a standardized protocol for thrombin generation measurement using the calibrated automated thrombogram: an international multicentre study. Thromb Res. 2012;130:929-34.

\section{Submit your next manuscript to BioMed Central and take full advantage of:}

- Convenient online submission

- Thorough peer review

- No space constraints or color figure charges

- Immediate publication on acceptance

- Inclusion in PubMed, CAS, Scopus and Google Scholar

- Research which is freely available for redistribution 